Пустовойт О. В., д.е.н., старший науковий співробітник ДУ «Інститут економіки та прогнозування Наџіональної академії наук України» м. Київ, Украӥна

DOI: https://doi.org/10.30525/978-9934-26-125-1-8

\title{
ПРОДУКТИВНІСТЬ ЕКОНОМІКИ УКРАЇНИ: ДИНАМІКА ТА ДЖЕРЕЛА
}

Після економічної кризи 2014-2015 pp. в Україні розпочалося економічне зростання. Для визначення його перспектив сьогодні важливо знати, як у посткризовий період змінювалася економічна продуктивність, яку науковці розглядають, як основний маркер коливань міжнародної конкурентоспроможності країн, їх здатності 
розвиватися в світовому господарстві. Тому проблематика, що пов'язана 3 економічною продуктивністю постійно перебуває в центрі уваги дослідників. Зокрема, понад чверть століття значна їх частина працювала над розумінням того, як різні набори матеріальних та нематеріальних ресурсів (tangible, intangible resources) і можливостей фірм приводять до відмінностей у їх продуктивності [1, с. 253]. Згодом ці знання були використані для створення теорії ресурсних переваг, яка в Україні ще є відомою як ресурсоорієнтований nidxid (resource-based view (RBV). Разом 3 тим, вплив матеріальних i нематеріальних ресурсів на економічну продуктивність країн, що розвиваються ще не стала предметом численних досліджень та дискусій. Хоча вони є актуальними, тому що можуть пролити світло не лише на джерела продуктивності, а i на здатність таких країн підтримувати економічне зростання в середньо- та довгостроковому періодах.

Для оцінювання змін в продуктивності національної економіки (national productivity) зазвичай використовується показник сукупної факторної продуктивності (total factor productivity (TFP). Прикладні дослідження свідчать, що для його розрахунку в країнах, що розвиваються доцільно використати методику, якою передбачається, що функція залежності пропозиції продукції від кількості застосованих у виробництві ресурсів виглядає так:

$$
Q=f(T R, I R),
$$

де $Q$ - обсяг виробництва в економіці; $T R$ - обсяг виробничого споживання матеріальних ресурсів економічного зростання; IR - обсяг виробничого використання нематеріальних ресурсів економічного зростання [2].

У межах наведеної функціональної залежності, в економіці на динаміку випуску традиційної продукції 3 незмінними 
споживчими властивостями впливає обсяг виробничого споживання матеріальних ресурсів (праці, землі, капіталу). Водночас на динаміку випуску нової продукції з кращими властивостями або 3 меншими витратами виробництва впливає обсяг виробничого використання нематеріальних peсурсів. У сфері виробництва запаси останніх нагромаджуються у формі різних видів нематеріального капіталу: людського, інституційного, соціального, інформаційно-правового, організаційного капіталу та капіталу організаційної культури. Описану закономірність можна подати у вигляді такого математичного запису:

$$
\Delta \mathrm{Q}=\Delta \mathrm{Q} \mathrm{TR}+\Delta \mathrm{Q} \mathrm{IR}=\Delta \mathrm{TR}+\Delta \mathrm{IR},
$$

де $\Delta Q$ - приріст виробництва в економіці, \%; $\triangle Q T R$ - приріст виробництва за рахунок виробничого споживання матеріальних ресурсів, \%; $\Delta Q I R$ - приріст виробництва за рахунок виробничого використання нематеріальних ресурсів, \%; $\Delta T R$ - приріст виробничого споживання матеріальних ресурсів, \%; $\Delta I R$ - приріст виробничого використання нематеріальних ресурсів, \%.

Зважаючи на те, що показник $\Delta Q$ IR відображає зростання виробництва, яке не можна пояснити витратами матеріальних ресурсів, його $є$ всі підстави трактувати, як приріст, що досягається за рахунок сукупної продуктивності праці, землі, капіталу. Методика піi оцінювання базується на такій системі рівнянь: $\Delta Q T R=\Delta T R ; \Delta Q I R=\Delta I R ; \Delta I R=\Delta Q-\Delta T R$. Для розрахунку показника $\Delta T R$ варто спиратися на таке припущення. Динаміка використання всіх матеріальних ресурсів в економіці є залежною від динаміки виробничого споживання сировини. Аргументувати це можна так. Для збільшення випуску традиційної продукції в економіку необхідно додатково залучити робочу силу, засоби 
виробництва та сировину. При цьому робоча сила та засоби виробництва нарощуються до рівня, який є необхідним, щоб переробити більші обсяги сировини. Тому динаміка іiі споживання може відображати закономірності змін у використанні інших видів матеріальних ресурсів.

У національних економіках переробляється багато видів сировини. Зміни у іiі використанні можна оцінити опосередковано за допомогою показника випуску первинних (природних) ресурсів. Їх ознакою $є$ те, що вони слугують основою для масового виробництва продукції. Тому коливання у випуску первинних ресурсів можна розглядати як показник змін у рівні виробничого споживання всіх інших видів сировини.

Кожна країна має свій власний набір первинних ресурсів, які здебільшого розділяють на три групи: продовольчі й енергетичні ресурси та конструкційні матеріали. На наш погляд, для України $є$ характерним такий набір первинних ресурсів: продовольчі ресурси, до складу яких входить продукція рослинництва (зернові, зернобобові, олійні культури, цукрові буряки, культури кормові, овочеві, плодові, ягідні) та тваринництва (м'ясо, молоко, яйця); конструкційні матеріали - залізна руда, вапняк, флюс, інший вапняковий камінь, що використовується для виготовлення вапна й цементу, каолін, гіпс, піски будівельні, щебінь; енергетичні ресурси - вугілля, торф, нафта, газ.

Наведена методика була використана для оцінювання коливань сукупної факторної продуктивності в Україні в 2013-2019 рр. (таблиця 1).

Дані таблиці свідчать, що в 2016-2019 рр. в Україні економічне зростання зумовлювали два чинники. Перший 3 них - це матеріальні ресурси, які додатково залучалися в сферу виробництва, у тому числі у вигляді сировини. 
Таблиця 1

Динаміка сукупної факторної продуктивності
в економіці України в 2013-2019 рр.

\begin{tabular}{|c|c|c|c|c|c|c|c|}
\hline Роки & 2013 & 2014 & 2015 & 2016 & 2017 & 2018 & 2019 \\
\hline $\begin{array}{l}\text { Виробництво } \\
\text { первинних } \\
\text { (природних) } \\
\text { ресурсів, млн тон } \\
\end{array}$ & 507,7 & 479,1 & 433,8 & 445,8 & 447,6 & 454,4 & 454,3 \\
\hline $\begin{array}{l}\text { Індекс виробни- } \\
\text { чого споживання } \\
\text { сировинних ресур- } \\
\text { сів в економіці, } \\
\% \text { до попереднього } \\
\text { року }\end{array}$ & 100,0 & 94,4 & 90,5 & 102,8 & 100,4 & 101,5 & 100,0 \\
\hline $\begin{array}{l}\text { Приріст індексу } \\
\text { споживання сиро- } \\
\text { винних ресурсів, } \\
\% \text { до попереднього } \\
\text { року }\end{array}$ & 0,0 & $-5,6$ & $-9,5$ & 2,8 & 0,4 & 1,5 & 0,0 \\
\hline $\begin{array}{l}\text { Індекс фізичного } \\
\text { обсягу ВВП, } \\
\% \text { до попереднього }\end{array}$ & & & & & & & \\
\hline $\begin{array}{l}\text { року } \\
\text { Приріст ВВП, } \\
\% \text { до попереднього } \\
\text { року }\end{array}$ & 100 & $-6,6$ & $-9,8$ & 102,4 & 102,5 & 103,4 & 103,3 \\
\hline $\begin{array}{l}\text { Приріст ВВП } \\
\text { за рахунок збіль- } \\
\text { шення споживання } \\
\text { матеріальних } \\
\text { ресурсів, \% }\end{array}$ & 0,0 & $-5,6$ & $-9,5$ & 2,8 & 0,4 & 1,5 & 0,0 \\
\hline $\begin{array}{l}\text { Приріст ВВП } \\
\text { за рахунок збіль- } \\
\text { шення викорис- } \\
\text { тання нематері- } \\
\text { альних ресурсів, \% }\end{array}$ & 0,0 & $-1,0$ & $-0,3$ & $-0,4$ & 2,1 & 1,9 & 3,3 \\
\hline
\end{tabular}

Джерело: складено автором за даними Державної служби статистики Украӥни [3] 
Другий - це нематеріальні ресурси, які визначали рівень сукупної факторної продуктивності. У 2014-2016 рр. вона мала від'ємні значення й уповільнювала економічне зростання, а в 2017-2019 pp. - позитивні - й прискорювала зростання економіки. Остання тенденція породжує ключове питання: в 2017-2019 рр. нематеріальні ресурси слугували джерелом для випуску переважно продукції 3 інноваційними та кращими властивостями чи 3 меншими витратами виробництва?

Знайти відповідь на це запитання можна шляхом оцінювання рівня технологічної складності товарного експорту України. Чому саме експорту? Пояснити це можна тим, що Україна продає на міжнародних ринках найбільш конкурентоспроможні товари, які в 2019 р. становили 26,6 \% у структурі ВВП і являли собою репрезентативну вибірку для збору спостережень. Методика оцінювання експорту базується на індексі вартості одиниці продукції, тобто одиничної вартості - UV (unit value index). За його допомогою економісти виявляють зміни в середній вартості неоднорідних товарних одиниць, на яку можуть впливати коливання як у наборі товарів, так і в їхніх цінах [4]. У цьому дослідженні середня вартість одиниці вітчизняного експорту оцінювалася в доларах США за 1 кілограм ваги набору товарів певної групи $j$ або сукупності товарних груп $t$.

Результати дослідження показали, що в 2013-2019 pp. вартість 1 кілограму ваги усієї сукупності товарів, які експортувалися Україною, зменшилася з 0,36 до 0,30 дол. $\mathrm{CША/кг.} \mathrm{Це} \mathrm{означає,} \mathrm{що} \mathrm{в} \mathrm{економіці} \mathrm{основним} \mathrm{чинником}$ зростання сукупної факторної продуктивності був процес скорочення виробничих витрат, який дав змогу зменшити ціни на експортні товари. 3 цього випливає, що в 2017-2019 pp. нематеріальні ресурси переважно слугували джерелом для 
випуску продукції не підвищеної технологічної складності 3 кращими властивостями та більшою вартістю, а 3 меншими витратами виробництва та нижчими цінами.

\section{Література:}

1. Kamasak R. The contribution of tangible and intangible resources, and capabilities to a firm's profitability and market performance. European Journal of Management and Business Economics. 2017. Vol. 26. № 2. P. 252-275. DOI: https://doi.org/10.1108/EJMBE-07-2017-015

2. Пустовойт О.В. Нематеріальні ресурси економічного зростання. Економіка Украӥни. 2019. № 9-10. С. 44-67.

3. Державна служба статистики України.

URL: http://www.ukrstat.gov.ua

4. Unit value index. Glossary statistical terms. OECD. URL: https://stats.oecd.org/glossary/detail.asp?ID=2810 